\title{
Innovation Characteristics and Adoption Opportunity of Bujangseta Technology for Tangerine Farming
}

\author{
Lizia Zamzami*, Agus Sugiyatno and Harwanto \\ Indonesian Citrus and Subtropical Fruits Research Institute, Batu, Indonesia \\ ${ }^{*}$ Corresponding author: liziazamzami@pertanian.go.id
}

\begin{abstract}
Indonesian Citrus and Subtropical Fruits Research Institute (ICSFRI) has generated a technology of Bujangseta (bearing fruits throughout the year) to increase citrus plant productivity and to support the sustainable availability of citrus fruits in the market. This study aims to identify the characteristics of Bujangseta technological innovation that might influence the adoption of the technology by farmers. The study was conducted in Banyuwangi Regency in November 2019 by using a census method to all 16 cooperator farmers of Bujangseta technology. This present study applied a descriptive analysis method based on the scoring and category of technological innovation characteristics. The results showed that the innovation characteristics of Bujangseta technology were: 1) it was very profitable since tangerine farming with the application of Bujangseta technology generated higher income than that without the application, 2) it was greatly appropriate with the local conditions as all production supplies were locally available, 3) it was easy to be applied because farmers did not suffer any complication to employ Bujangseta practice, 4) it was easily observed since the results of Bujangseta implementation were easy to be observed visually by farmers and 5) it was easily trial-tested as the method of Bujangseta was easy to try and apply. Therefore, this new technology had a very high adoption opportunity rate, showing that the technology had a great chance of being adopted by farmers.
\end{abstract}

Keywords: citrus farm; dissemination; horticulture; tangerine; technology adoption

Cite this as: Zamzami, L., Sugiyatno, A., \& Harwanto. (2021). Innovation Characteristics and Adoption Opportunity of Bujangseta Technology for Tangerine Farming. Caraka Tani: Journal of Sustainable Agriculture, 36(1), 144-154. doi: http://dx.doi.org/10.20961/carakatani.v36i1.43381

\section{INTRODUCTION}

Citrus is one of the commercial horticultural produces that has a high economic value. Moreover, based on the Decree of the Minister of Agriculture of the Republic of Indonesia no. 472/Kpts/RC.040/6/2018 regarding the location of national agricultural area, citrus commodity is still a development priority by the Ministry of Agriculture. In 2017, the total citrus harvest area in Indonesia was 56,757 ha, with a total production of 2,295,310 tons (Database Agricultural Statistics, 2019). However, as citrus is a seasonal fruit, the harvest period in Indonesia only occurs in certain months; thus, it is not available throughout the years (Banafanu et al., 2019). The peak harvesting season of almost $60 \%$ citrus occurs in May to August, while the harvesting season of the remaining $40 \%$ of citrus, which is mostly a secondary harvest, is spread unevenly in other few months (Hanif and Zamzami, 2012; Supriyanto et al., 2019). This condition needs to be improved to support better citrus productivity and supply. Therefore, a technology that could produce fruit at off season is required so that not all trees bear fruit at

\footnotetext{
* Received for publication July 29, 2020

Accepted after corrections January 20, 2021
} 
the same time (Gunadi, 2017) and therefore, the availability of the produce in the market can be met continuously.

The Indonesian Agency of Agricultural Research and Development (IAARD) through Indonesian Citrus and Subtropical Fruits Research Institute (ICSFRI) has generated the technology of Bujangseta (Buah berjenjang sepanjang tahun/bearing fruits throughout the year) (IAARD, 2020). This technology enables citrus, specifically the tangerine crops, to produce fruits in stages throughout the year. Hence, while regular tangerine harvest period is 1-2 year $^{-1}$, the harvest period resulted from Bujangseta application is able to be leveraged up to 5-7 times a year (Supriyanto, 2018). Thereby, Bujangseta could increase the productivity of tangerine crops and support the availability of tangerine fruits in the market continually. Other advantage that can be obtained from the implementation of Bujangseta technology is that it improves the quality of the tangerine fruits to be a premium grade, where the size of the fruit is relatively uniform with a good taste and smooth fruit skin. In addition, it is able to improve the health of tangerine crops (Cahyono and Supriyanto, 2018; ICSFRI, 2018).

Bujangseta technology incorporates several combinations of cultivation treatments, namely canopy management, fertilization management and pest and disease management. Canopy management includes pruning for maintenance, i.e., removing branches that are dry or attacked by pests, water sprouts that grow straight and fast, shoots that grow inside the canopy and the remains of fruit stalks after harvesting. The purposes of this pruning for maintenance are: 1) to maintain the health of the tree canopy, where the air circulation improves and the sunlight can penetrate maximally inside the canopy so that the physiological process of the plants can take place optimally and 2) to maintain the vegetative and generative growth in balance, which leads to the flowering process (Cahyono and Supriyanto, 2018; Suratno et al., 2018).

Fertilization management includes providing fertilizer to meet nutrient requirements for plants and preparing plant branches for the flowering process. Fertilizer application in Bujangseta technology is conducted by giving manure or other organic materials at least 1 sack $(20 \mathrm{~kg})$ tree $^{-1}$. Then applying NPK fertilizer (15-15-15) or other similar fertilizers at $0.5 \mathrm{~kg}$ tree ${ }^{-1}$, which is applied every 3 months. Furthermore, a 100 g NPK (15-15-15) fertilizer solution $+25 \mathrm{~g} \mathrm{ZA} / 20$ liters tree ${ }^{-1}$ are also applied every 1.5 months after applying NPK solid fertilizer. In addition, the application of $50 \mathrm{gr}$ $\mathrm{MgSO} 4$ (kieserite) into the $3^{\text {rd }}$ liquid fertilization aims to increase the level of fruit sweetness (Supriyanto et al., 2019).

Pest and disease management focuses on pathogens of dull dotted diseases resulting in the citrus peels to become dotted, dull and dirty. Pests causing dull dotted diseases that need to be aware of are thrips, rust mites, red mites, scale insects and sooty molds. They are often associated with bed insects, brown aphids and black aphids. Additionally, the control measures of other plant-disturbing organisms must be considered according to the level of attack (Cahyono and Supriyanto, 2018).

The technology of Bujangseta, as an innovation to sustain citrus production along the year, needs to be introduced and disseminated to citrus farmers. Innovation is an idea, object or practice that is perceived as a brand-new thing by individuals or other units of adoption (Rogers et al., 2019). Farmer's perception to assess an innovation is closely related to the adoption of the innovation. The level of adoption of an innovation relies on the perception of the adopter about the innovation's characteristics (Ridwan et al., 2008; Zebua et al., 2019). Moreover, Muharam and Subarna (2005) highlight that the adoption level of technology components often depends on innovation's characteristics, adopters' characteristics and the behavior of agent of change (researcher/extension officer). Furthermore, the technology adoption normally occurs after going through a mental process. The process starts from an attention, then it grows to an interest and subsequently becomes a desire to try out the innovation. This process drives the adopter to make a decision and eventually arrives at the attempt to encourage the application of technology as an action called adoption (Hendayana, 2014). There are five phases in the process of innovation decision usually experienced by farmers, i.e. knowledge, persuasion, decision, implementation and confirmation (Rogers et al., 2019). The implementation of technological innovation for citrus suitable for environmental condition is necessary to achieve a sustainable citrus agribusiness (Primilestari and Purnama, 2019). 
Considering that Bujangseta is a new released technology, it is important to evaluate the nature of the innovation of Bujangseta technology so that the adoption opportunity can be measured and the process of technology transfer can be designed effectively to increase the adoption rates. There has not been any study assessing the innovation profile of Bujangseta. Therefore, this study aims to identify the innovation characteristics of Bujangseta technology and its adoption opportunity. The article will complement the literature on Bujangseta, specifically in the aspect of its innovation characteristics.

\section{MATERIALS AND METHOD}

The study was conducted in November 2019 in Banyuwangi Regency as one of the tangerine production centers in East Java Province of Indonesia and as the location of demonstration plot of Bujangseta technology assembled by ICSFRI. In terms of geographic position, Banyuwangi Regency is located at the easternmost of Java Island, between $7^{\circ} 43^{\prime}-8^{\circ} 46^{\prime}$ South latitude and between $113^{\circ} 53^{\prime}$ - $121^{\circ} 38^{\prime}$ East longitude. The area of Banyuwangi Regency is about $5,782.50 \mathrm{~km}^{2}$, which is the largest regency in East Java Province. The average temperature is $27.9^{\circ} \mathrm{C}$, while the average of relative humidity is $75.2 \%$ and the average rainfall reaches $122 \mathrm{~mm}$ (BPS - Statistics of Banyuwangi, 2019; Government of Banyuwangi, 2020).

Primary data were collected by census using a questionnaire to all 16 cooperator farmers whose citrus farms were treated with Bujangseta technology for demonstration plot of ICSFRI. These farmers were spread from four farmer groups and they have actively participated as the cooperator farmers for Bujangseta technology since 2018. The questionnaire was arranged in such a way as to obtain data related to farmers' perceptions regarding the nature of Bujangseta technology that has been introduced.

The characteristic of technology innovation can be measured from several aspects, namely: 1) relative profit, reflecting the difference in financial benefit between the new technology and the conventional way done by farmers, 2) compatibility, indicating the level of technological compatibility with other supporting aspects, such as the availability of agricultural production facilities, agroecological conditions, market form and local socio-cultural values,
3) complexity, denoting the level of technical effort in the stages of the use of the technology compared to the common way done by farmers, 4) trialability, showing the level of easiness to apply the technology and 5) observability, signifying the effectiveness or the results of the technology that can be observed visually by farmers (Mundy, 2000). Therefore, in measuring the characteristics of technological innovation, a rating scale for each of these aspects is made as presented in Table 1. Similar method had been used in other research conducted by Ridwan et al. (2008), Ridwan et al. (2012) and Erythrina et al. (2013). As for this study, Bujangseta technology was assessed as an intact technology.

Table 1. The scale and category of technology innovation characteristics

\begin{tabular}{|c|c|c|}
\hline $\begin{array}{c}\text { Aspects of } \\
\text { technology } \\
\text { characteristics }\end{array}$ & Scale & Category \\
\hline \multirow[t]{5}{*}{ Relative profit } & 1 & Very unprofitable \\
\hline & 2 & Unprofitable \\
\hline & 3 & Moderate \\
\hline & 4 & Profitable \\
\hline & 5 & Very profitable \\
\hline \multirow[t]{5}{*}{ Compatibility } & 1 & Very incompatible \\
\hline & 2 & Incompatible \\
\hline & 3 & Moderate \\
\hline & 4 & Compatible \\
\hline & 5 & Very compatible \\
\hline \multirow[t]{5}{*}{ Complexity } & 1 & Very difficult \\
\hline & 2 & Difficult \\
\hline & 3 & Moderate \\
\hline & 4 & Not difficult \\
\hline & 5 & Very easy \\
\hline \multirow[t]{5}{*}{ Trialability } & 1 & $\begin{array}{l}\text { Very difficult to be } \\
\text { trial-tested }\end{array}$ \\
\hline & 2 & $\begin{array}{l}\text { Difficult to be trial- } \\
\text { tested }\end{array}$ \\
\hline & 3 & Moderate \\
\hline & 4 & Easy to be trial-tested \\
\hline & 5 & $\begin{array}{l}\text { Very easy to be trial- } \\
\text { tested }\end{array}$ \\
\hline \multirow[t]{5}{*}{ Observability } & 1 & $\begin{array}{l}\text { Very difficult to be } \\
\text { observed }\end{array}$ \\
\hline & 2 & $\begin{array}{l}\text { Difficult to be } \\
\text { observed }\end{array}$ \\
\hline & 3 & Moderate \\
\hline & 4 & Easy to be observed \\
\hline & 5 & $\begin{array}{l}\text { Very easy to be } \\
\text { observed }\end{array}$ \\
\hline
\end{tabular}


One of the adoption decisions could be influenced by the characteristics of the technology, which could be assessed from those five aspects. An easier technology to be carried out is more likely to be adopted (Ridwan et al., 2008). Furthermore, each of the aspect has a weight in influencing the decision of farmers to adopt the technology, which will be used as a reference in determining the value categories achieved. The valuation of technological innovation of Bujangseta is resulted from the average weighting given by the research team of Bujangseta (Table 2).

Table 2. Weighting evaluation of aspects of technology characteristics of Bujangseta

\begin{tabular}{lc}
\hline $\begin{array}{c}\text { Aspects of technology } \\
\text { characteristics }\end{array}$ & Weighting \\
\hline Relative profit & 25.00 \\
Compatibility & 18.33 \\
Complexity & 15.00 \\
Trialability & 21.67 \\
Observability & 20.00 \\
\hline Total & 100.00 \\
\hline
\end{tabular}

The highest scale of valuation that could be given by farmers was 5 , so the expected value of each aspect was the multiplication of the highest scale multiplied by the weight of the aspect (Table 3). The characteristics of technological innovation was the sum of the value of those five aspects.

\section{RESULTS AND DISCUSSION}

\section{Citrus farming performance in Banyuwangi Regency}

The development of citrus farming in Banyuwangi Regency has been very encouraging within the past few years. The area of harvest has increased significantly from 7,026 ha in 2015 to 13,789 ha (equals to citrus population of $5,515,600$ trees) in 2017 , or there was an increase in harvested area of 6,763 ha (96.26\%). Therefore, the total production of citrus has also increased from 205,684 tons in 2015 to 539,157 tons in 2017, making Banyuwangi Regency as the largest citrus production center area in East Java Province (Database Agricultural Statistics, 2019) and contributed $58.68 \%$ to the total production of citrus in East Java. Furthermore, the type of citrus grown in this district has been dominated by tangerine.

\section{Demographic profile of the respondents}

The characteristics of the cooperator farmer respondents (Figure 1) showed that based on age, the majority of respondents of citrus farmers were aged between 51 and 60 years $(38.7 \%)$. Thus, they were still included in the productive age category (BPS - Statistics Indonesia, 2020), despite being no longer young. Generally, the adoption of technology is influenced by the farmers' age, as previous study has shown that farmer's age positively and significantly affects the technology adoption (Kinyangi, 2014).

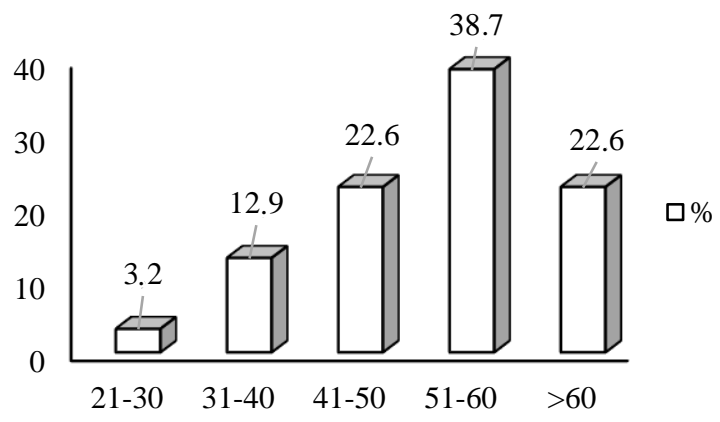

a.

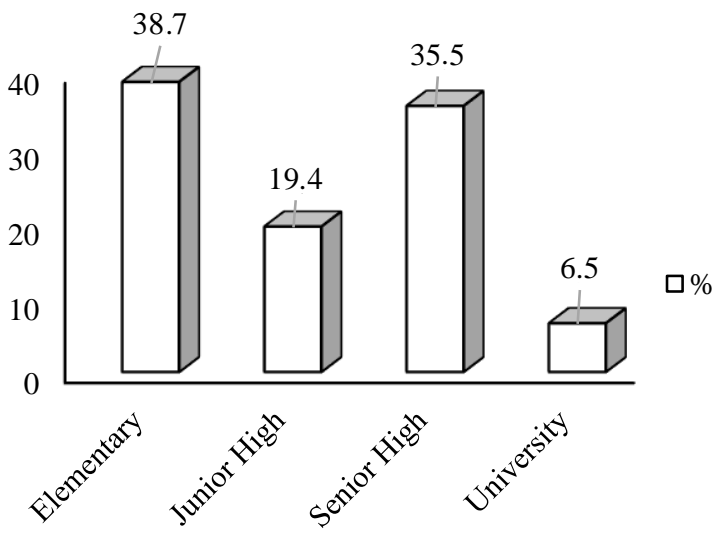

b.

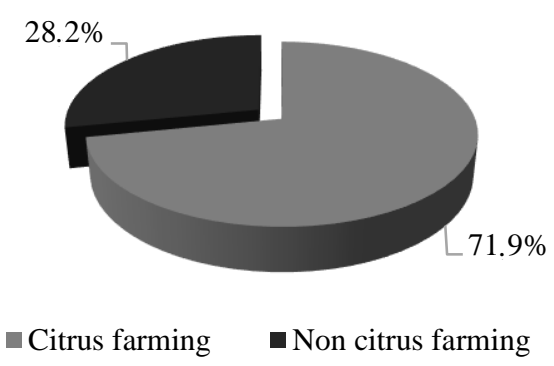

c.

Figure 1. Profile of respondents: (a) Age; (b) Education; and (c) Primary livelihood 


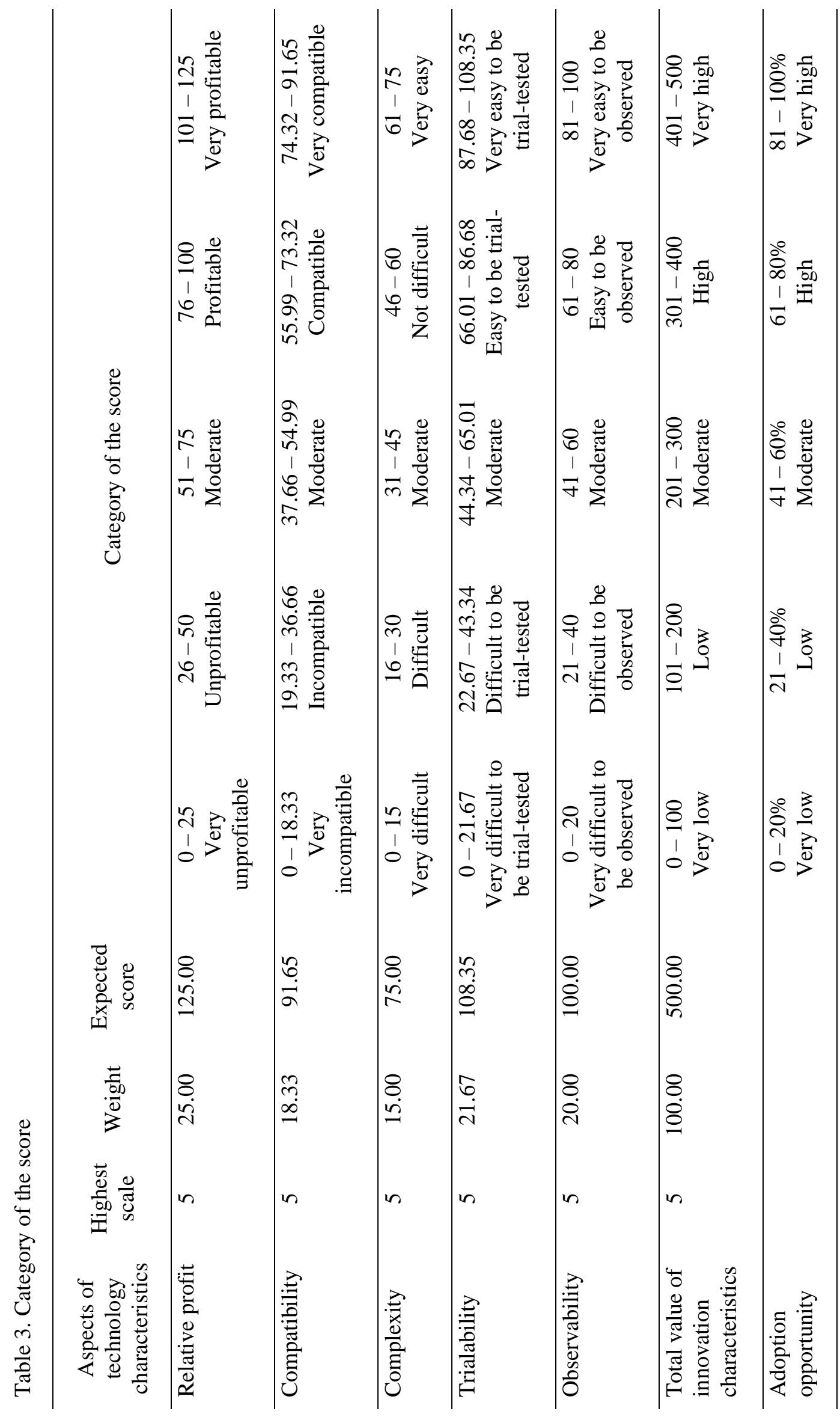


In terms of education, the majority of respondents graduated from elementary school $(38.7 \%)$ and high school (35.5\%). However, all these cooperator farmers had attended trainings or technical guidance on Bujangseta technology application conducted by ICSFRI. The level of education generally affects the literacy, knowledge and the understanding of farmers. Several study results showed that technology adoption is influenced by educational level (Abebe et al., 2013; Khonje et al., 2015; Wongnaa et al., 2018).

All respondents were the owners of their citrus orchards. Furthermore, citrus farming was the primary livelihood for most of the respondents (71.9\%), while others $(28.2 \%)$ considered citrus farming as the secondary source of revenue since they were actually food crop farmers. The type of primary livelihood may affect the allocation of time given by farmers to their farming. Farmers usually allocated more time for their citrus farming when they were citrus farmers as primary occupation. Moreover, previous study showed that primary occupation had a positive and very significant relationship with the adoption of agricultural technology (Chepng'eno et al., 2012).

With regards to experience, respondents had the experience in citrus farming for more than 9 years, on average. Hence, they had sufficient skills in performing citrus cultivation. The farming experience may also put an influence on the technology adoption, as indicated in the study by Wongnaa et al. (2018) that experience in farming is also a factor that affects the adoption of technology. The same result was shown by Wahyudi and Hasibuan (2011).

\section{Evaluation of technology innovation characteristics of Bujangseta}

Basically, the process of technology adoption is demanding and takes time. There are stages involved in the process. When farmers are faced with alternative of technologies, their responses often vary depending on many considered factors. One of the factors influencing the accelerated diffusion of adoption is the characters of the innovation (Darusalam et al., 2017; Suryani and Prawiranegara, 2019). Normatively, a technology must be perceived as a need, provides advantages, is compatible, has the ability to overcome limiting factors, employs existing resources, is affordable to farmers, is not complicated and is easy to observe (Hendayana, 2014). In order to facilitate citrus farmers' acceptance of Bujangseta technology, the innovation characteristics of this technology were evaluated.

The score of each aspect of technology given by farmers towards Bujangseta technology considerably varied. The scores were then multiplied by the weight of each aspect of the technological characteristics. Thus, the value of each characteristic of Bujangseta technology obtained is presented in Table 4 and the categories of innovation and adoption opportunity of the technology are given in Table 5. Based on the results, the total value of each aspect of technology characteristics was relatively high. Therefore, the innovation characteristics of Bujangseta technology belonged to the category of very profitable, very compatible with local conditions, not difficult to be applied, easily observed and easily trial-tested.

Table 4. Value of innovation characteristics of Bujangseta technology in Banyuwangi Regency

\begin{tabular}{lccccr}
\hline $\begin{array}{c}\text { Aspects of technology } \\
\text { characteristics }\end{array}$ & $\begin{array}{c}\text { Minimum } \\
\text { score }\end{array}$ & $\begin{array}{c}\text { Maximum } \\
\text { score }\end{array}$ & Mean & Weight & Value \\
\hline Relative profit & 4 & 5 & 4.80 & 25.00 & 120.00 \\
Compatibility & 3 & 5 & 4.19 & 18.33 & 76.80 \\
Complexity & 2 & 5 & 3.71 & 15.00 & 55.65 \\
Trialability & 2 & 5 & 4.00 & 21.67 & 80.00 \\
Observability & 3 & 5 & 3.53 & 20.00 & 76.49 \\
\hline
\end{tabular}

According to farmers' experiences with regards to relative profit, tangerine farming with the application of Bujangseta technology generated higher income than that without the application of Bujangseta technology. Hence, the category for the aspect of relative profit was very profitable (Table 5). Occasionally, farmers still experienced low selling prices during peak harvesting season, however, in times of slack harvesting season and high price conditions, they still had fruits on the plants to be harvested and thereby they still gained a good income. 
This was in line with the economic analysis, which had been done (Table 6). The cost and revenue structure showed that tangerine farming applying Bujangseta technology was more profitable than the farming without Bujangseta application. The $\mathrm{R} / \mathrm{C}$ ratio of citrus farming with Bujangseta application was 4.95 , while that of citrus farming without Bujangseta application was 2.90 (Table 6). Therefore, the $\mathrm{R} / \mathrm{C}$ ratio of citrus farming with Bujangseta application was higher than that of citrus farming without Bujangseta application. The aspect of profitability may raise the farmers' interest in adopting the new technology, as suggested by Wahyudi and Hasibuan (2011) that for new technology to be adopted by farmers, it must provide benefits for farmers. Accordingly, the use of the technology could increase the farmers' income. This is consistent with Dorji et al. (2016) and Selvaraj (2009) that new technology tends to provide chances to increase yield, production and income considerably.

Table 5. Category of innovation characteristics of Bujangseta technology

\begin{tabular}{lrc}
\hline \multicolumn{1}{c}{ Aspects of technology characteristics } & Value & Category \\
\hline Relative profit & 120.00 & Very profitable \\
Compatibility & 76.80 & Very compatible \\
Complexity & 55.65 & Not difficult \\
Trialability & 80.00 & Easy to be trial-tested \\
Observability & 76.49 & Easy to be observed \\
\hline Total & 408.94 & \\
\hline
\end{tabular}

Table 6. Cost and revenue structure of tangerine farming with and without Bujangseta application per hectare per year

\begin{tabular}{lccrc}
\hline \multirow{2}{*}{\multicolumn{1}{c}{ Description }} & \multicolumn{2}{c}{ Without Bujangseta application } & \multicolumn{2}{c}{ With Bujangseta application } \\
\cline { 2 - 5 } & Value (IDR) & Percentage $(\%)$ & Value (IDR) & Percentage (\%) \\
\hline Cost of fertilizers & $14,501,706$ & 46.11 & $20,865,588$ & 51.08 \\
Cost of pesticides & $7,999,182$ & 25.44 & $6,320,591$ & 15.47 \\
Cost of labor & $8,947,059$ & 28.45 & $13,662,127$ & 33.45 \\
Total cost & $31,447,947$ & 100.00 & $40,848,307$ & 100.00 \\
Revenue & $91,300,000$ & & $202,120,000$ & \\
Profit & $59,852,053$ & & $161,271,693$ & \\
R/C ratio & 2.90 & & 4.95 & \\
\hline
\end{tabular}

In practicing Bujangseta technology, the farmer respondents did not experience any difficulties in providing production inputs such as fertilizers and pesticides, as well as other production equipment such as pruning shears, sprayer, etc. All these production inputs and facilities were available locally nearby the farming sites. The yields produced throughout the year were also in accordance with market conditions since the produce would be available all year round in the market. Thus, Bujangseta technology was considered very compatible with local conditions (Table 5). Similar result was shown by Darusalam et al. (2017), leading to a higher potential of technology adoption by farmers.

In addition, the specific method of fertilizer application in Bujangseta technology, particularly the NPK fertilizer, was applied in the form of solid and dissolve materials alternately. The application of solid NPK fertilizer was every 3 months and that of NPK fertilizer solution was every 1.5 months. Dorji et al. (2016) suggested that the management of proper nutrients is important to produce optimum yield and production. At this state, farmers claimed that they did not undergo any complication to do such practice. They also stated that there was no technical problem in trying and performing maintenance pruning and pest and diseases controlling, because these practices could be accomplished without great difficulties. Hence, based on the level of complexity and trialability, Bujangseta technology was categorized as simple and easy to be trial-tested (Table 5). This was in accordance with Efendy and Hutapea (2010) and Ridwan et al. (2012) that an easier and trial-able technology has more opportunities to be adopted. 
Table 5 also shows that in terms of observability, farmers considered that the effectiveness of results of Bujangseta technology implementation was easy to be observed. In oneyear farming period, farmers applying Bujangseta technology had managed to perform harvesting for five times. The production yield was higher than that of non-Bujangseta tangerine farming. Previous study by Supriyanto et al. (2019) showed that despite the less total number of fruits in one tangerine plant treated with Bujangseta technology, the plant was able to produce $50.7 \mathrm{~kg}$ tree $^{-1}$ year $^{-1}$ fruits, whereas the plant without Bujangseta application only produced $40.2 \mathrm{~kg}$ tree $^{-1}$ year $^{-1}$. The fruit quality treated with Bujangseta was bigger in size and heavier in weight than those that were not treated with Bujangseta (Supriyanto et al., 2019).

\section{Adoption opportunity of Bujangseta technology}

According to Hendayana (2014), adoption opportunity reflects a situation that describes an opportunity for individuals to apply or not apply the technology. Thus, understanding the category of adoption opportunity of Bujangseta technology is also necessary as part of the technology evaluation. Based on farmers' perception of Bujangseta technology that had been previously discussed, the total value of innovation characteristic of Bujangseta technology was 408.94 and was categorized as very high. Furthermore, the analysis result revealed that the adoption opportunity of Bujangseta technology was $81.78 \%$ or in the category of very high (Table 7). This means that the technology was applicable and had a great opportunity to be adopted by more tangerine farmers. Such outcome was in line with Suryani and Prawiranegara (2019) that technologies with high adoption opportunity are feasible to be developed. Furthermore, the adoption opportunity directly affects significantly and positively to the adoption willingness of farmers (Q. Li et al., 2019). Therefore, it is expected that citrus farmers would consider this technology and eventually adopt the technology to increase the performance of their citrus farms and productions. This was in accordance with Halijah and Altandjung (2019) that farmers' adoption is not merely knowing the technology, yet implementing it properly in their farming practices.

Table 7. Total value of innovation characteristics and adoption opportunity of Bujangseta technology

\begin{tabular}{lcl}
\hline \multicolumn{1}{c}{ Description } & Value & Category \\
\hline Total value of innovation characteristics & 408.94 & Very high \\
Adoption opportunity & $81.78 \%$ & Very high \\
\hline
\end{tabular}

Subsequent phase to reach farmers' adoption was to put transfer process of the new technology under intensive implementation in many ways, as suggested by Sumarno et al. (2017) that increasing farmers' access to the technology resources can be done through increasing the frequency of extension and dissemination that reach more farmer groups and farmers. In order to accelerate the adoption of new technologies, various efforts through dissemination, training and assistance to farmers needed to be enhanced, as per recommendation by Siswanto and Karmawati (2011). This was in line with the result of study by Kinyangi (2014) that training positively and significantly affects the adoption of a technology. Furthermore, the impact of technical training on farmers' adoption willingness and behavior is significantly positive (B. Li et al., 2021). A previous study by Nakano et al. (2018) has shown that after attending training, the level of farmers' technology adoption increase immediately. Therefore, the technology inventor and disseminator must be actively involved in the dissemination phase of Bujangseta technology, as recommended by Efendy and Hutapea (2010) that technology advisers need to play an active role in the process of technology transfer to farmers. Moreover, the demonstration plot is still necessary since it is mentioned as the most preferred and accessible source of technology information to farmers, while the support of agricultural extension officer is also significant in influencing the technology transfer and adoption (Kadar et al., 2016).

\section{CONCLUSIONS}

The technology of Bujangseta, which enabled tangerine plants to produce fruits in stages throughout the year, had innovation characteristics that were very profitable, very 
compatible with local conditions, not difficult to apply, easy to be observed and easy to be trial-tested. Therefore, this technology had very high adoption opportunity rate $(81.78 \%)$, meaning that the technology provides a large opportunity to be adopted by broader tangerine farmers. There were several alternatives of technology transfer to be done, such as dissemination, extension, training, demonstration plot and assistance to farmers. Further research may examine the level of adoption after the dissemination of the technology has been run completely.

\section{ACKNOWLEDGEMENT}

We would thank to the Indonesian Agency of Agricultural Research and Development (IAARD), Ministry of Agriculture of the Republic of Indonesia, for providing the full research fund.

\section{REFERENCES}

Abebe, G. K., Bijman, J., Pascucci, S., \& Omta, O. (2013). Adoption of improved potato varieties in Ethiopia: The role of agricultural knowledge and innovation system and smallholder farmers' quality assessment. Agricultural Systems, 122, 22-32. https:// doi.org/10.1016/j.agsy.2013.07.008

Banafanu, M., Siregar, A. R., Jusni, \& Sirajuddin, S. N. (2019). Analysis supply chain tangerine orange in the District of South Central Timor. Advances in Environmental Biology, 13(6), 21-26. https://doi.org/10.22587/aeb.2019.13. 6.4

BPS - Statistics of Banyuwangi. (2019). Banyuwangi Regency in figures 2019. Statistics Indonesia. Retrieved from https:// banyuwangikab.bps.go.id/publication/2019/0 8/16/55769fbf5800ac0c5d22e2ea/kabupatenbanyuwangi-dalam-angka-2019.html

BPS - Statistics Indonesia. (2020). Istilah sosial dan kependudukan. Statistics Indonesia. Retrieved from https://www.bps.go.id/istilah/ index.html?Istilah_page $=4$

Cahyono, A., \& Supriyanto, A. (2018). Teknologi bujangseta: buah berjenjang sepanjang tahun. Indonesian Citrus and Subtropical Fruits Research Institute. Retrieved from http:// balitjestro.litbang.pertanian.go.id/wp-content/
uploads/2018/07/BUJANGSETA-2018.pdf

Chepng'eno, W., Koech, P., Cumo, C., \& Sulo, T. (2012). Socioeconomic factors affecting the adoption of Marakwet County Kenya. Journal of Emerging Trends in Economics and Management Sciences (JETEMS), 3(4), 312317. Retrieved from https://journals.co.za/doi/ 10.10520/EJC126579

Darusalam, H., Widjayanthi, L., \& Subekti, S. (2017). Proses Adopsi inovasi pupuk cair organik (biofish) berbahan dasar ikan laut pada komoditas padi di Kecamatan Muncar Kabupaten Banyuwangi. KANAL: Jurnal Ilmu Komunikasi, 6(1), 9-20. https://doi.org/ 10.21070/kanal.v6i1.1420

Database Agricultural Statistics. (2019). Agricultural database by commodity. Ministry of Agriculture of the Republic of Indonesia. Retrieved from https://aplikasi2.pertanian. go.id/bdsp/en/commodity

Dorji, K., Lakey, L., Chophel, S., Dorji, S. D., \& Tamang, B. (2016). Adoption of improved citrus orchard management practices : a micro study from Drujegang growers, Dagana, Bhutan. Agriculture \& Food Security, 5(3), 18. https://doi.org/10.1186/s40066-016-0050-z

Efendy, J., \& Hutapea, Y. (2010). Analisis adopsi inovasi teknologi pertanian berbasis padi di Sumatera Selatan dalam perspektif komunikasi. Jurnal Pengkajian dan Pengembangan Teknologi Pertanian, 13(2), 119-130. Retrieved from http://ejurnal. litbang.pertanian.go.id/index.php/jpengkajian/ article/view/1399

Erythrina, Indrasti, R., \& Muharam, A. (2013). Kajian sifat inovasi komponen teknologi untuk menentukan pola diseminasi pengelolaan tanaman terpadu padi sawah. Jurnal Pengkajian dan Pengembangan Teknologi Pertanian, 16(1), 45-55. Retrieved from http://ejurnal.litbang.pertanian.go.id/index.ph p/jpengkajian/article/view/4734

Government of Banyuwangi. (2020). Banyuwangi Regency. https://www.banyuwangikab.go.id/

Gunadi, I. G. A. (2017). Sejarah dan perkembangan produksi tanaman di luar musim. Discussion Issue and Technology: Pengembangan Teknologi Budidaya di Luar Musim sebagai Alternatif mewujudkan 
Indonesia Berdaulat Pangan, 1-7. Retrieved from https://simdos.unud.ac.id/uploads/file penelitian_1_dir/1b5d8ace4087c378a26c1a1e a7334eeb.pdf

Halijah, \& Altandjung, R. I. (2019). Determinasi peluang adopsi teknologi budidaya ternak ayam KUB di Papua Barat. Jurnal Pengkajian Dan Pengembangan Teknologi Pertanian, 22(2), 201-212. http://dx.doi.org/10.21082/ jpptp.v22n2.2019.p215-226

Hanif, Z., \& Zamzami, L. (2012). Trend jeruk impor dan posisi indonesia sebagai produsen jeruk dunia. Workshop Rencana Aksi Rehabilitasi Agribisnis Jeruk Keprok Soe yang Berkelanjutan untuk Substitusi Impor di NTT, March, 107-114. https://doi.org/10.13140/ RG.2.1.4207.7601

Hendayana, R. (2014). Persepsi dan adopsi teknologi. Bogor: Balai Besar Pengkajian dan Pengembangan Teknologi Pertanian. Retrieved from http://malut.litbang.pertanian. go.id/images/stories/4a.-PERSEPSI-DAN-AD OPSI-TEKNOLOGI.pdf

IAARD [Indonesian Agency for Agricultural Research and Development]. (2020). 700 teknologi inovatif pertanian. Bogor: IAARD Press.

ICSFRI [Indonesian Citrus and Subtropical Fruits Research Institute]. (2018). Bujangseta, buahkan jeruk berjenjang sepanjang tahun. Balai Penelitian Tanaman Jeruk dan Buah Subtropika. Retrieved from http://balitjestro. litbang.pertanian.go.id/bujangseta-buahkan-je ruk-berjenjang-sepanjang-tahun/

Kadar, L., Siregar, H., Intan, E., \& Putri, K. (2016). Faktor-faktor yang berpengaruh terhadap adopsi varietas unggul jagung putih di Kabupaten Grobogan-Jawa Tengah. Informatika Pertanian, 25(2), 215-220. http://dx.doi.org/10.21082/ip.v25n2.2016.p21 5-220

Khonje, M., Manda, J., Alene, A. D., \& Kassie, M. (2015). Analysis of adoption and impacts of improved maize varieties in Eastern Zambia. World Development, 66, 695706. https://doi.org/10.1016/j.worlddev.2014. 09.008

Kinyangi, A. A. (2014). Factors influencing the adoption of agricultural technology among smallholder farmers in Kakamega North SubCounty, Kenya [Master Thesis]. Nairobi, Kenya: University of Nairobi. Retrieved from http://erepository.uonbi.ac.ke/bitstream/handl e/11295/76086/Kinyangi_Factors\%25\%0920i nfluencing_the_adoption_of_agricultural_tec hnology_amo\%09ng_smallholderfarmers.pdf ?sequence $=1$

Li, B., Ding, J., Wang, J., Zhang, B., \& Zhang, L. (2021). Key factors affecting the adoption willingness, behavior, and willingnessbehavior consistency of farmers regarding photovoltaic agriculture in China. Energy Policy, 149, 112101. https://doi.org/10.1016/ j.enpol.2020.112101

Li, Q., Zeng, F., Mei, H., Li, T., \& Li, D. (2019). Roles of motivation, opportunity, ability, and trust in the willingness of farmers to adopt green fertilization techniques. Sustainability, 11(24), 6902. https://doi.org/10.3390/su1124 6902

Muharam, A., \& Subarna, T. (2005). Sifat inovasi teknologi komponen teknologi PTT padi di Jawa Barat. Bandung: BPTP Jawa Barat.

Mundy, P. (2000). Adopsi dan adaptasi teknologi baru. Bogor: PAATP3.

Nakano, Y., Tsusaka, T. W., Aida, T., \& Pede, V. O. (2018). Is farmer-to-farmer extension effective? The impact of training on technology adoption and rice farming productivity in Tanzania. World Development, 105, 336-351. https://doi.org/10.1016/j.world dev.2017.12.013

Primilestari, S., \& Purnama, H. (2019). Teknologi budidaya jeruk di lahan gambut untuk meningkatkan produktivitas dan pendapatan petani di Kabupaten Tanjung Jabung Barat. Seminar Nasional Lahan Suboptimal, September, 978-979. Retrieved from http://conference.unsri.ac.id/index.php/lahans uboptimal/article/view/1467

Ridwan, H., Hilman, Y., Sayekti, A. L., \& Suhardi. (2012). Sifat inovasi dan peluang adopsi teknologi pengelolaan tanaman terpadu krisan dalam pengembangan agribisnis krisan di Kabupaten Sleman, DI Yogyakarta. Jurnal Hortikultura, 22(1), 86-94. https://doi.org/ 10.21082/jhort.v22n1.2012.p85-93

Ridwan, H., Ruswandi, A., Winarno, Muharam, 
A., \& Hardiyanto. (2008). Sifat Inovasi dan aplikasi teknologi pengelolaan terpadu kebun jeruk sehat dalam pengembangan agribisnis jeruk di Kabupaten Sambas, Kalimantan Barat. Jurnal Hortikultura, 18(4), 477-490. Retrieved from http://ejurnal.litbang.pertanian .go.id/index.php/jhort/article/view/899

Rogers, E. M., Singhal, A., \& Quinlan, M. M. (2019). Diffusion of innovations 1. In an integrated approach to communication theory and research (3rd Edition). New Yok: Routledge. https://doi.org/10.4324/97802037 10753-35

Selvaraj, K. N. (2009). Impact of improved vegetable farming technology on farmers' livelihoods in India. Acta Horticulturae, 809, 121-126. https://doi.org/10.17660/ActaHortic .2009 .809 .9

Siswanto, \& Karmawati, E. (2011). Percepatan adopsi teknologi PHT kakao di Sulawesi Selatan. Prosiding Seminar Nasional Inovasi Perkebunan, 148-155. Retrieved from http://perkebunan.litbang.pertanian.go.id/wpcontent/uploads/2012/04/perkebunan_prosdE NIP11_MP_Siswanto.pdf

Sumarno, J., Sari, F., \& Hiola, I. (2017). Socioeconomic factors affecting farmers adopting innovation of integrated crop management of maize in Gorontalo. Informatika Pertanian, 26(2), 99-110. http://dx.doi.org/10.21082/ip. v26n2.2017.p99-110

Supriyanto, A. (2018). Tangkal harga anjlog panen raya jeruk, bujangseta solusinya. Balai Penelitian Tanaman Jeruk dan Buah Subtropika. Retrieved from http://balitjestro. litbang.pertanian.go.id/tangkal-harga-anjlogpanen-raya-jeruk-bujangseta-solusinya/

Supriyanto, A., Purbiati, T., \& Cahyono, A. (2019). Bujangseta vs non bujangseta: pola pembuahan, produksi, mutu buah dan perubahan hormonal pada jeruk siam. Prosiding Seminar Nasional Perhorti 2019, 2019, 93-100. Retrieved from https://perhorti. id/eprosiding/files/prosiding_perhorti_2019.p df

Suratno, Kasutjianingati, \& Firgiyanto, R. (2018). Penerapan teknologi bujangseta (buah berjenjang sepanjang tahun) dalam mendukung keberhasilan pengembangan sentral agribisnis jeruk di Banyuwangi. Prosiding Seminar Nasional Hasil Penelitian dan Pengabdian Masyarakat 2018, 156-161. Retrieved from https://publikasi.polije.ac.id/ index.php/prosiding/article/view/1213

Suryani, A., \& Prawiranegara, D. (2019). Peluang penerapan berbagai inovasi teknologi dalam meningkatkan produksi pertanian di Jawa Barat. Creative Research Journal, 5(1), 33-40. http://dx.doi.org/10.34147/crj.v5i01.198

Wahyudi, A., \& Hasibuan, M. (2011). Faktorfaktor yang mempengaruhi adopsi teknologi lada di Kabupaten Belitung. Buletin Ristri, 2(1), 63-72. Retrieved from https://www. researchgate.net/publication/317712353_Fakt or-faktor_yang_mempengaruhi_adopsi_tekno logi_lada_di_Kabupaten_Belitung

Wongnaa, C. A., Awunyo-Vitor, D., \& Bakang, J.-E. A. (2018). Factors affecting adoption of maize production technologies: A astudy in Ghana. The Journal of Agricultural Science, 13(1), 81-99. http://doi.org/10.4038/jas.v13 i1.8303

Zebua, D. D. N., Priyanto, S. H., \& Sunaryanto, L. T. (2019). An analysis of wheat farming: calculations and perceptions. Caraka Tani: Journal of Sustainable Agriculture, 34(2), 200-212. https://doi.org/10.20961/carakatani. v34i2.28862 